\title{
Evaluation of the economic impact of COVID-19 on Brazilian private dental clinics: A cross-sectional study
}

\author{
Natália Lins de Souza Villarim ${ }^{\mathrm{a}}$, Isis de Araújo Ferreira Muniz ${ }^{\mathrm{a}, *}$, Danyel Elias da Cruz Perez ${ }^{\mathrm{b}}$, \\ Hercílio Martelli Junior ${ }^{\mathrm{c}}$, Renato Assis Machado ${ }^{\mathrm{d}, \mathrm{e}}$, \\ Yuri Wanderley Cavalcanti ${ }^{\mathrm{a}}$ and Paulo Rogério Ferreti Bonan ${ }^{\mathrm{a}}$ \\ ${ }^{a}$ Postgraduate Program in Dentistry, Federal University of Paraíba, Brazil \\ ${ }^{\mathrm{b}}$ Department of Clinical and Preventive Dentistry, Federal University of Pernambuco, Brazil \\ ${ }^{c}$ Postgraduate Program in Health Sciences and Primary Health Care, State University of Montes Claros, Brazil \\ ${ }^{\mathrm{d}}$ Hospital for Rehabilitation of Craniofacial Anomalies, University of São Paulo (HRAC/USP), Bauru, São Paulo, \\ Brazil \\ ${ }^{\mathrm{e}}$ Department of Oral Diagnosis, School of Dentistry, University of Campinas (FOP/UNICAMP), Piracicaba, \\ São Paulo, Brazil
}

Received 24 June 2021

Accepted 24 September 2021

\begin{abstract}
.
BACKGROUND: The changes in dental care in the face of the COVID-19 pandemic resulted in the need for greater financial investment by dentists in biosafety measures and increase in the costs of dental consultations.

OBJECTIVE: To evaluate the economic impact of the COVID-19 pandemic on dental practices in private clinics in Brazil. METHODS: A cross-sectional study was carried out, using an online questionnaire indexed in Google Forms, and distributed among dentists. The data obtained were analyzed using the IBM SPSS 25.0 software, evaluating the factors associated with strong or very strong impact on the participants' income and the factors that motivated the dentists to look for a credit line. Multiple logistic regression models were constructed to identify the associated factors. Variables with $p<0.05$ were considered statistically significant.

RESULTS: Most participants were female, with a median age of 35 years. Dentists who are most concerned about their professional future $(\mathrm{OR}=3.134 ; 95 \% \mathrm{CI}$ : 1.804-5.445), who have longer office hours $(\mathrm{OR}=2.056$; 95\% CI: 1.198-3.529), who had the greatest impact on the flow of patients $(\mathrm{OR}=16.358 ; 95 \% \mathrm{CI}$ : 9.408-28.443) and in need of investing in infrastructure $(\mathrm{OR}=1.756 ; 95 \% \mathrm{CI}$ : 1.014-3.041), had the greatest impact on monthly earnings.

CONCLUSIONS: The pandemic and the new biosafety recommendations for care during this period had a negative impact on the income of Brazilian dental offices and increased the chance of seeking credit to alleviate the financial deficit.
\end{abstract}

Keywords: Dentists, dental economics, dentist's practice patterns, dental offices, COVID-19

*Address for correspondence: Isis de Araújo Ferreira Muniz, Cidade Universitária, Campus I, João Pessoa, Paraíba 58051-900, Brazil. E-mail: isismuniz13@hotmail.com.

\section{Introduction}

The Coronavirus Disease 2019 (COVID-19) pandemic has been profoundly affecting the entire world. In addition to the thousands of cases registered by the disease and the health system's overload, combating 
the outbreak of COVID-19 also results in economic challenges for many countries [1]. Due to the transmission of SARS-CoV-2 between humans, it occurs mainly through the inhalation of respiratory droplets loaded with the virus and contact with contaminated surfaces [2, 3], measures such as social distance, isolation, and quarantine have been adopted to reduce the contamination rate of the disease and this has caused a worldwide reduction in economic activity [4].

Due to the production of aerosols and exposure to salivary and respiratory droplets during dental treatment, dental offices are considered to be potential transmission routes for COVID-19, have a high risk of cross-infection and dentists are more susceptible to exposure to the virus [5-9]. Given this, many health regulatory agencies recommended at the beginning of the pandemic the suspension of elective treatments and the performance of only urgent and emergency dental procedures [10], in addition to the establishment of rigorous and effective biosafety protocols for dental care [11-13], which guide the use of level 2 or 3 personal protective equipment (PPE), aerosol control strategies, new disinfection protocols for equipment and office surfaces, and proper patient screening [14-17].

The changes in dental care in the face of the COVID-19 pandemic resulted in the need for greater financial investment by dentists in biosafety measures, in the reduction of their care, and the significant increase in the costs of dental consultations, thus reflecting on monetary implications in dental practices worldwide $[4,10]$. The Irish Dental Association reported in its study that a fifth of the interviewed dentists ended their dental care and almost half of the participants expect a financial loss close to $90 \%$ in the midst of the COVID-19 outbreak [18]. In the United Kingdom, dental practices are expected to have a significant loss due to the suspension of routine visits [19]. In the United States of America (USA), the pandemic resulted in the dental economy's paralysis, with more than three-quarters of dental clinics serving only emergencies and another $18 \%$ closed completely [20].

Governments around the world have implemented strict policies to contain the COVID-19 pandemic. Brazil, like other countries, suspended elective dental treatments from March to July 2020 and established new biosafety measures that should be followed throughout the pandemic, which could result in financial impacts in dental offices $[4,10]$. Thus, the present study was carried out to evaluate the pandemic's economic impact on dental practices in private clinics in Brazil.

\section{Methods}

The present work is an observational, cross-sectional study. The study was approved by the Research Ethics Committee of the Health Sciences Center of the Federal University of Paraiba, Brazil (CAAE no. 31757120.7.0000.5188). The research was conducted in full compliance with the ethical principles of research involving human beings and followed the Declaration of the Helsinki World Medical Association (version 2008) [21]. The study was reported following the STROBE guidelines for observational studies [22].

The sample calculation was performed using the online tool OpenEpi. For the calculation, the miniimal population size of 337 dentists registered at the Federal Council of Dentistry (FCD) (https://web site.cfo.org.br/estatisticas/quantidade-geral-de-entid ades-e-active professionals/ Accessed: 05.05.2020). It was considered that $70 \%$ (anticipated frequency) of the participants would be aware of the FCD's recommendations. A 95\% confidence interval and a design effect (deff) of 1.5 were established to assign a correction in the sample size between $40 \%$ and 50\% and safeguard the desired precision [23]. Based on these parameters, a sample size of 484 dentists distributed throughout Brazil was defined, with the inclusion criterion of dental surgeons who worked in private clinics and who were following the consent form of the research. Participants who did not complete the questionnaire adequately were excluded.

The instrument for collecting this research was an online semi-structured questionnaire, developed by researchers based on consultations with other studies that evaluated the impact of the pandemic on dental practice in other countries, added to Google Forms, which was in accordance with the new guidance of the CONEP present in Circular Letter 01/2021Conep [7, 12, 24-26]. Its first page referred to the free and informed consent term, which guaranteed the confidentiality of the data and informed the participants about the objectives of the study and their voluntary participation. Dentists' consent to participate in the study was implied when they clicked the "next" button to answer the survey. The questionnaire had 58 closed questions and was divided into four sections: Socio-demographic profile; Knowledge and 
adherence of professionals to the new biosafety standards and care practices guided by the World Health Organization (WHO) and FCD; Dental care and its possible financial implications during the COVID-19 pandemic; Assessment of anxiety and fear of professionals about becoming infected in their workplace.

Before the beginning of the research, a pilot test was carried out, with the questionnaire being randomly sent to dentists of different age groups, who worked in a private clinic $(n=12)$. The data of these respondents were submitted to an internal consistency analysis, which showed a Cronbach's alpha of 0.941 , and the instrument was appropriate for the research. The questionnaire was then released by the researchers from 20/06/2020 to 11/08/2020 in Whatsapp, Facebook and Instagram groups, and online forums (sample for convenience). Participants' help was requested to forward the questionnaire to other dentists (sample by snowball sampling) so that it could be distributed throughout the country.

The data obtained from the online platform were exported and tabulated in an Excel spreadsheet, with subsequent analysis using the IBM SPSS software (25.0, IBM Corporation, Armonk, New York, USA). The factors associated with the strong or very strong impact on the income of dentists in Brazil were verified. Also, it was verified the factors that motivated the dentists to look for a credit line. The independent variables consisted of individual factors (Sex,
Age Group, Time of Office, Postgraduate and Concern about professional future), and changes related to dental practice after the start of the pandemic (Reduction of the flow of patients, need for investment in infrastructure, increase in PPE costs, increase in clinical hour costs and absorption of costs by professionals). Multiple logistic regression models were constructed to identify the associated factors. Variables with $p<0.20$ were included in the final model. Odds ratio (OR) and $95 \%$ confidence intervals $(95 \%$ $\mathrm{CI})$ values were generated for variables included in the final model. Variables with $p<0.05$ were considered statistically significant.

\section{Results}

The responses of 559 dentists, distributed throughout Brazil, were evaluated. During data analysis, the alternative answers "I prefer not to declare" and "I don't know how to answer" were considered as lost value and did not participate in the analysis. Most of the participants were female and had some type of postgraduate degree. The median age was 35 years, with a minimum age of 22 and a maximum of 69 years.

Independent variables such as age group, time in the office, concern about professional future, impact on patient flow, need to invest in infrastructure,

Table 1

Distribution of independent variables according to the perception of Brazilian dentists on the impact on monthly income $(n=559)$

\begin{tabular}{|c|c|c|c|c|c|c|}
\hline \multirow[t]{3}{*}{ Variables } & \multirow[b]{3}{*}{$n$} & \multicolumn{4}{|c|}{ Impact on income } & \multirow[t]{3}{*}{$p$-value } \\
\hline & & \multicolumn{2}{|c|}{ Low Impact } & \multicolumn{2}{|c|}{ High Impact } & \\
\hline & & $\%$ & $n$ & $\%$ & & \\
\hline \multirow[t]{2}{*}{ Gender } & Male & 62 & 11.1 & 87 & 15.6 & 0.194 \\
\hline & Female & 196 & 35.1 & 214 & 38.3 & \\
\hline \multirow[t]{2}{*}{ Age range } & Up to 34 years & 144 & 25.8 & 128 & 22.9 & 0.002 \\
\hline & 35 years or more & 114 & 20.4 & 173 & 30.9 & \\
\hline \multirow[t]{2}{*}{ Office time } & 0 to 10 years & 166 & 29.7 & 145 & 25.9 & $<0.001$ \\
\hline & More than 10 years & 92 & 16.5 & 156 & 27.9 & \\
\hline \multirow{2}{*}{ Postgraduate } & No & 39 & 7.0 & 46 & 8.2 & 0.957 \\
\hline & Yes & 219 & 39.2 & 255 & 45.6 & \\
\hline \multirow{2}{*}{$\begin{array}{l}\text { Concern about } \\
\text { professional future }\end{array}$} & Little worried & 152 & 27.5 & 65 & 11.8 & $<0.001$ \\
\hline & Very worried & 103 & 18.6 & 233 & 42.1 & \\
\hline \multirow[t]{2}{*}{ Impact on patient flow } & Low impact & 188 & 33.8 & 43 & 7.7 & $<0.001$ \\
\hline & High impact & 69 & 12.4 & 257 & 46.1 & \\
\hline \multirow[t]{2}{*}{ Need to invest in infrastructure } & No & 121 & 25.6 & 86 & 18.2 & $<0.001$ \\
\hline & Yes & 94 & 19.9 & 172 & 36.4 & \\
\hline \multirow[t]{2}{*}{ Increased PPE costs } & Up to $60 \%$ & 191 & 40.0 & 206 & 43.1 & $<0.001$ \\
\hline & More than $60 \%$ & 21 & 4.4 & 60 & 12.6 & \\
\hline \multirow[t]{2}{*}{ Increased clinical hour costs } & Up to $60 \%$ & 181 & 39.0 & 214 & 46.1 & 0.009 \\
\hline & More than $60 \%$ & 20 & 4.3 & 49 & 10.6 & \\
\hline \multirow{2}{*}{$\begin{array}{l}\text { Absorption of costs } \\
\text { by the professional }\end{array}$} & Pass on costs & 116 & 24.6 & 146 & 31.0 & 0.643 \\
\hline & Absorb costs & 97 & 20.6 & 112 & 23.8 & \\
\hline
\end{tabular}

Pearson's Chi-Square Test. $n=$ Absolute Frequency. $\%=$ Relative Frequency. $p$-value $=$ Significance level $=5 \%$. 
Table 2

Factors associated with the strong or very strong impact on the income of Brazilian dentists $(n=395)$

\begin{tabular}{|c|c|c|c|c|c|c|}
\hline \multirow[t]{2}{*}{ Variables } & \multirow[t]{2}{*}{$\mathrm{B}$} & \multirow[t]{2}{*}{ S.E. } & \multirow[t]{2}{*}{$p$-value } & \multirow[t]{2}{*}{ OR } & \multicolumn{2}{|c|}{ 95\% C.I. } \\
\hline & & & & & Lower & Upper \\
\hline Gender (female) & -0.568 & 0.310 & 0.067 & 0.566 & 0.309 & 1.040 \\
\hline $\begin{array}{l}\text { Concerns about professional future } \\
\text { (very worried) }\end{array}$ & 1.142 & 0.282 & $<0.001$ & 3.134 & 1.804 & 5.445 \\
\hline Office time (more than 10 years) & 0.721 & 0.276 & 0.009 & 2.056 & 1.198 & 3.529 \\
\hline Impact on patient flow (high impact) & 2.795 & 0.282 & $<0.001$ & 16.358 & 9.408 & 28.443 \\
\hline Need to invest in infrastructure (yes) & 0.563 & 0.280 & 0.044 & 1.756 & 1.014 & 3.041 \\
\hline
\end{tabular}

$\mathrm{B}=$ Multiple Logistic Regression Coefficient. S.E.=Standard Error. $p$-value $=$ Significance level=5\%. OR=Odds Ratio. 95\%CI $(\mathrm{OR})=$ Confidence Interval $95 \%$ of Odds Ratio .

increased cost of PPE and increased cost of clinical hours are associated with dentists' perception of the impact strong or very strong in the office's monthly income. The distributions of responses to the analyzed variables are shown in Table 1.

Through multiple logistic regression, the factors that are associated with the strong or very strong impact on the income of dentists have been evaluated (Table 2). It was observed that dentists who are more concerned about their professional future $(\mathrm{OR}=3.134$; 95\% CI: 1.804-5.445), who have longer office hours (OR $=2.056$; 95\% CI: 1.198-3.529), who had greater impact on patient flow $(\mathrm{OR}=16.358 ; 95 \%$ CI: 9.408-28.443) and needing to invest in infrastructure (OR $=1.756$; 95\% CI: $1.014-3.041)$, had the greatest impact on monthly earnings.
The distribution of independent variables according to the intention of Brazilian dental surgeons to seek a credit line is shown in Table 3. It was observed that the postgraduate variables, office time, concern about professional future, impact on patient flow, need for investing in infrastructure, increased costs of PPE, and increased costs of clinical hours are associated with the demand for a credit line.

Through multiple logistic regression, the factors that are associated with the search for a credit line by dentists in Brazil have been evaluated (Table 4). It was observed that dentists who are more concerned with professional future $(\mathrm{OR}=3.411 ; 95 \% \mathrm{CI}$ : 2.117-5.497), who had a greater impact on the flow of patients $(\mathrm{OR}=2.164$; 95\% CI: $1.343-3.488)$ and with the need to invest in infrastructure $(\mathrm{OR}=3.246 ; 95 \%$

Table 3

Distribution of independent variables according to the intention to seek a credit line

\begin{tabular}{|c|c|c|c|c|c|c|}
\hline \multirow[t]{3}{*}{ Variables } & & \multicolumn{4}{|c|}{ Credit line } & \multirow[t]{3}{*}{$p$-value } \\
\hline & & \multicolumn{2}{|c|}{$\begin{array}{l}\text { Will not use } \\
\text { credit line }\end{array}$} & \multicolumn{2}{|c|}{$\begin{array}{l}\text { Will use } \\
\text { credit line }\end{array}$} & \\
\hline & & $n$ & $\%$ & $n$ & $\%$ & \\
\hline \multirow[t]{2}{*}{ Gender } & Male & 66 & 13.0 & 80 & 15.8 & 0.387 \\
\hline & Female & 178 & 35.2 & 182 & 36.0 & \\
\hline \multirow[t]{2}{*}{ Age range } & Up to 34 years & 118 & 23.3 & 108 & 21.3 & 0.106 \\
\hline & 35 years or more & 126 & 24.9 & 154 & 30.4 & \\
\hline \multirow{2}{*}{ Office time } & 0 to 10 years & 139 & 27.5 & 124 & 24.5 & 0.030 \\
\hline & More than 10 years & 105 & 20.8 & 138 & 27.3 & \\
\hline \multirow[t]{2}{*}{ Postgraduate } & No & 23 & 4.5 & 40 & 7.9 & 0.047 \\
\hline & Yes & 221 & 43.7 & 222 & 43.9 & \\
\hline \multirow{2}{*}{$\begin{array}{l}\text { Concerns about } \\
\text { professional future }\end{array}$} & Little worried & 145 & 28.9 & 61 & 12.2 & $<0.001$ \\
\hline & Very worried & 96 & 19.1 & 200 & 39.8 & \\
\hline \multirow{2}{*}{ Impact on patient flow } & Low impact & 136 & 27.1 & 74 & 14.7 & $<0.001$ \\
\hline & High impact & 105 & 20.9 & 187 & 37.3 & \\
\hline \multirow[t]{2}{*}{ Need to invest in infrastructure } & No & 131 & 29.0 & 70 & 15.5 & $<0.001$ \\
\hline & Yes & 84 & 18.6 & 166 & 36.8 & \\
\hline \multirow[t]{2}{*}{ Increased PPE costs } & Up to $60 \%$ & 194 & 42.5 & 189 & 41.4 & 0.001 \\
\hline & More than $60 \%$ & 22 & 4.8 & 51 & 11.2 & \\
\hline \multirow[t]{2}{*}{ Increased clinical hour costs } & Up to $60 \%$ & 191 & 43.0 & 189 & 42.6 & $<0.001$ \\
\hline & More than $60 \%$ & 17 & 3.8 & 47 & 10.6 & \\
\hline \multirow{2}{*}{$\begin{array}{l}\text { Absorption of costs by } \\
\text { the professional }\end{array}$} & Pass on costs & 113 & 25.2 & 137 & 30.5 & 0.287 \\
\hline & Absorb costs & 100 & 22.3 & 99 & 22.0 & \\
\hline
\end{tabular}

Pearson's Chi-Square Test. $n=$ Absolute Frequency. $\%=$ Relative Frequency. $p$-value $=$ Significance level $=5 \%$. 
Table 4

Factors associated with the search for a credit line by dental surgeons in Brazil $(n=387)$

\begin{tabular}{|c|c|c|c|c|c|c|}
\hline \multirow[t]{2}{*}{ Variables } & \multirow[t]{2}{*}{$\mathrm{B}$} & \multirow[t]{2}{*}{ S.E. } & \multirow[t]{2}{*}{$p$-value } & \multirow[t]{2}{*}{ OR } & \multicolumn{2}{|c|}{ 95\% C.I. } \\
\hline & & & & & Lower & Upper \\
\hline $\begin{array}{l}\text { Concerns about professional future } \\
\text { (very worried) }\end{array}$ & 1.227 & 0.243 & $<0.001$ & 3.411 & 2.117 & 5.497 \\
\hline Office time (more than 10 years) & 0.376 & 0.243 & 0.122 & 1.456 & 0.904 & 2.344 \\
\hline Postgraduate (Yes) & -0.646 & 0.415 & 0.119 & 0.524 & 0.232 & 1.181 \\
\hline Impact on patient flow (high impact) & 0.772 & 0.243 & 0.002 & 2.164 & 1.343 & 3.488 \\
\hline Need to invest in infrastructure (yes) & 1.177 & 0.236 & $<0.001$ & 3.246 & 2.042 & 5.158 \\
\hline
\end{tabular}

$\mathrm{B}=$ Multiple Logistic Regression Coefficient. S.E. $=$ Standard Error. $p$-value $=$ Significance level $5 \%$. OR=Odds Ratio. 95\%CI $(\mathrm{OR})=$ Confidence Interval $95 \%$ of Odds Ratio.

CI: 2.042-5.158), have a greater chance of resorting to some credit line.

\section{Discussion}

The impact of the COVID-19 pandemic on society is already notorious and its consequences on socials, economics and psychologicals will reflect in the short and long term [27-29]. In dentistry, it was necessary to re-adapt dental practice to offer a safer environment and reduce the risk of contamination by SARS-CoV2 [8]. The increase in costs of materials and PPE, together with the reduction of services and adaptation of the infrastructure have been causing an economic deficit in this class [4]. It was found in this study that the concern with the professional future, patient flow, office time, and the need to invest in infrastructure are factors that are associated both with the impact on the monthly income of Brazilian dentists and with the increased chance of using the credit line.

With the suspension of elective dental care and the closing of some private practices during the COVID19 contention period, it was inevitable that dentists would reflect and think about the impact the pandemic was having on their monthly income and how it will reflect in their professional future. The majority of dentists interviewed are concerned about their professional future due to: not knowing how the emergency in Brazil will end; not knowing if patients will be able to afford dental treatment after the end of the pandemic and the possibility of closing the office due to the financial crisis after the end of the pandemic. A study carried out in the United Kingdom revealed that $71.5 \%$ of dental offices would only be able to sustain their commercial finances for a period of up to three months, after which they could collapse without significant financial support [30].

The decrease in the flow of patients in dental services is being observed all over the world, both in urgent emergency care and in elective care. In Beijing, China, the use of emergency dental services at the beginning of the pandemic was reduced by $38 \%$ when compared to another period, with a negative influence of COVID-19 on the behavior of the population to seek dental care, due to fear of contamination during care [31]. In a study carried out with orthodontists in Nigeria, it was seen that $63 \%$ of the participants had a moderate to severe negative economic impact in their office. Almost all respondents reported that the reduction in the number of patients seen will affect their future practice of orthodontics [32]. Also, the demand for dental care in private offices is directly related to the patient's financial situation and employment. In the USA, $70 \%$ of all dental clinic patients have dental insurance offered for work. With the significant increase in unemployment expected in the coming months, there is a great risk that the demand for dental care will suffer a significant negative impact [20].

In the present study, it was observed that dentists who had been in private practice for more than 10 years had the greatest impact on monthly income $(\mathrm{OR}=2.056$; 95\% CI: $1.198-3.529)$. This result can be explained due to the exclusive dedication of these professionals to the clinic, which is often their only source of income [33]. Ferneini (2020) warns in his study that as the pandemic begins to subside, many dentists may not be able to restart their clinical practice due to economic implications [27]. A survey conducted in Germany reports that after 90 days of suspension of elective dental care due to the pandemic, most offices are expected to have minimum profitability next year, not including any remuneration for the professional, thus resulting in a negative financial income throughout the year, when considering that the dentist's salary is deducted from the office's revenue [34].

In addition to the economic difficulties caused by the decrease in the flow of patients and reduction in the amount of elective care, many dental 
clinics still face the need for adjustments in their infrastructure and the acquisition of PPE and materials suitable for care during the pandemic, which increases your expenses. Recent studies reinforce that the use of PPE is essential for professionals in their protection against the SARS-CoV-2 virus during care, being essential the use of disposable masks (conventional surgery and mask with filter level 2 or 3), glasses protection, disposable shoe protector, disposable hat, face shield, waterproof medical coat, disposable gown and procedure gloves $[6$, 34-36].

During the pandemic, there was an exacerbated increase in the value of this equipment and limited access to purchase these items, due to the insufficient global supply of PPE, being mainly destined to public institutions $[37,38]$. In a study carried out in Brazil, it was observed that changes in the biosafety protocols during the COVID-19 pandemic increased the costs of a dental appointment by 19.05 times, the main cause of this increase being the increase in the number of PPE and their values found in the market [4].

Several dental offices were not prepared to assist patients in the face of this "new normality" required by the pandemic. The need to control the dispersion of aerosol particles made several professionals invest in the infrastructure of their office, further increasing their expenses in a time of financial crisis. Proffitt describes some measures aimed at decreasing physical risk, such as the need for high-speed air evacuation, the use of advanced filtration, purification and decontamination systems, installation of negative pressure rooms or isolation rooms airborne infections, as well as strict cleaning and disinfection protocols for all equipment and the office after treatment. The author recognizes that some of these mitigations are not quick and simple undertakings and that they require a significant additional cost, thus making treatments even more expensive and with a massive impact on the number of daily procedures performed [39].

Given this new reality that the pandemic caused in the dental sector, it is often not feasible to maintain the amount of the consultation charged previously, and it is often necessary to pass on this increase in costs to the patient. According to Barabari and Moharamzadeh, it is expected that the cost of dental treatment will increase in the future, due to the need for additional resources, changes in dental practice, segregation of patients in the waiting room, and a decrease in the number of daily visits [35]. As a way of mitigating the risk of cross-infection and mitigating the impact of the pandemic on the volume of consultations with patients in the dental office, dentists are incorporating telehealth programs in their clinic that have been assisting them, allowing preventive measures to be taken and keeping in touch with patients [40].

In the present study, it was seen that the Brazilian dentists who are most likely to use a credit line are those who are concerned about their professional future, suffered a negative impact on the flow of patients, and showed the need to invest in the office's infrastructure. Therefore, the dental sector must receive the necessary attention from Organs competent bodies so that financial strategies are developed with low interest rates and aim to mitigate the strong financial impact in the offices. Ali et al. affirmed that, in developed countries, the commitment of governments and health regulatory bodies to helping dental clinics to recover during the pandemic is already seen, but when comparing it to the underdeveloped world, it was not observed any policy that could help dentists prevent their clinics from closing due to financial constraints [41].

In Brazil, the Federal Council of Dentistry has requested economic measures from the Ministry of Economy, stressing the importance of granting immediate access to specific credit lines, in addition to requesting the postponement of the payment of taxes for a period of six months and the reduction of income tax rates, as well as the release of the withdrawal from the Severance Indemnity Fund (FGTS) for employees, among other measures that intend to mitigate this economic impact [42]. Therefore, it is essential that while these economic measures are not released, dentists act by reorganizing their offices, reducing costs, and keeping profitability to a minimum [34].

It is important to note that this research had some limitations, such as the possible risk of selfselection and the approach of participants through social media, online forums, and messaging applications. Also, the study was carried out in the period $(06 / 20 / 2020$ to $08 / 11 / 2020)$ when clinics were still predominantly providing urgent / emergency care, with the gradual return of elective care, which means that the impact may be greater than what has been assessed. Another limitation of this research was the impossibility of long-term monitoring of the participants, thus limiting the evaluation of the financial impact of this dental class after the end of the pandemic, which leads to the need to conduct a new study that addresses this variable. 


\section{Conclusion}

The present study observed that the pandemic and the new biosafety recommendations for care during this period harmed the income of Brazilian dental offices and increased the chance of these credit lines seeking credit to alleviate the financial deficit. In presenting these findings, we highlight the importance of the support of competent public agencies, such as the Federal Council of Dentistry, of working together with the Federal Government in the creation and approval of credit lines with low interest rates and developing proposals that aim to mitigate the financial impact suffered by this class, to avoid the permanent closure of some offices during and after the pandemic.

\section{Acknowledgments}

Not applicable.

\section{Conflict of interest}

The authors declare that they have no conflict of interest.

\section{Funding}

This research did not receive any specific grant from funding agencies in the public, commercial, or not-for-profit sectors.

\section{References}

[1] Wilder-Smith A, Freedman DO. Isolation, quarantine, social distancing and community containment: pivotal role for old-style public health measures in the novel coronavirus (2019-nCoV) outbreak. J Travel Med. 2020;27(2):taaa020. https://doi.org/10.1093/jtm/taaa020

[2] Chan JFW, Yuan S, Kok KH, Para KKW, Chu H, Yang $\mathrm{J}$, et al. A familial cluster of pneumonia associated with the 2019 novel coronavirus indicating person-toperson transmission: a study of a family cluster. Lancet. 2020;395(10223):514-23. https://doi.org/10.1016/S01406736(20)30154-9

[3] Liu T, Hu J, Kang $\mathrm{M}$, Lin L, Zhong $\mathrm{H}$, Xiao J, et al. Transmission dynamics of 2019 novel coronavirus (2019-nCoV). The Lancet. 2020. http://dx.doi.org/ 10.1101/2020.01.25.919787

[4] Cavalcanti YW, Silva RO, Ferreira LF, Lucena EHG, Souza AMLB, Cavalcante DFB, et al. Economic impact of new biosafety recommendations for dental clinical practice during COVID-19 pandemic. Pesqui Bras Odontopediatria Clin Integr. 2020. http://dx.doi.org/10.1590/scielopreprints. 781

[5] Cagetti MG, Cairoli JL, Senna A, Campus G. COVID19 Outbreak in North Italy: An Overview on Dentistry. A Questionnaire Survey. Int J Environ Res Public Health. 2020;17(11):3835-46. http://dx.doi.org/10.3390/ ijerph17113835

[6] Izzetti R, Nisi M, Gabriele M, Graziani F. COVID-19 Transmission in Dental Practice: Brief Review of Preventive Measures in Italy. J Dent Res. 2020. http://dx.doi. org/10.1177/0022034520920580

[7] Kamate SK, Sharma S, Thakar S, Srivastava D, Sengupta K, Hadi A, et al. Assessing Knowledge, Attitudes and Practices of dental practitioners regarding the COVID-19 pandemic: A multinational study. Dent Med Probl. 2020;57(1):11-17. http://dx.doi.org/10.17219/dmp/119743

[8] Peng X, Xu X, Li Y, Cheng LX, Ren B. Transmission routes of $2019-\mathrm{nCoV}$ and controls in dental practice. Int J Oral Sci. 2020;12 (1):1-6. http://dx.doi.org/10.1038/s41368020-0075-9

[9] Banaee S, Claiborne DM, Akpinar-Elci M. Occupational health practices among dental care professionals before and during the COVID-19 pandemic. Work. 2021;68:993-1000. http://dx.doi.org/10.3233/WOR-205319

[10] Farooq I, Ali S. COVID-19 outbreak and its monetary implications for dental practices, hospitals and healthcare workers. Postgrad Med J. 2020. http://dx.doi. org/10.1136/postgradmedj-2020-137781

[11] Alharbi A, Alharbi S, Alqaidi S. Guidelines for dental care provision during the COVID-19 pandemic. Saudi Dent J. 2020;32(4):181-6. http://dx.doi.org/10.1016/ j.sdentj.2020.04.001

[12] Khader Y, Nsour MA, Al-Batayneh OB, Saadeh R, Bashier H, Alfagih M, et al. Dentists' Awareness, Perception, and Attitude Regarding COVID-19 and Infection Control: Cross-Sectional Study Among Jordanian Dentists. Jmir Public Health Surveill. 2020;6(2):e18798. http:// dx.doi.org/10.2196/18798

[13] Ren YF, Rasubala L, Malmstrom H, Eliav E. Dental Care and Oral Health under the Clouds of COVID19. JDR Clin Trans Res. 2020;5(3):202-10. http://dx. doi.org/10.1177/2380084420924385

[14] Bescos R, Casas-Agustench P, Belfield L, Brookes Z, Gabaldón T. Coronavirus Disease 2019 (COVID19):Emerging and Future Challenges for Dental and Oral Medicine. J Dent Res. 2020. 22034520932149. doi:10.1177/0022034520932149

[15] Meng L, Hua F, Bian Z. Coronavirus Disease 2019 (COVID-19):Emerging and Future Challenges for Dental and Oral Medicine. J Dent Res. 2020;99(5):481-7. http://dx.doi.org/10.1177/0022034520914246

[16] Thomé G, Bernardes SR, Guandalini S, Guimarães MCV. Manual de boas práticas em biossegurança para ambientes odontológicos. 41p. 2020. [Acessed 30 Abr 2020]. http://website.cfo.org.br/wp-content/uploads/2020/04/cfolanc\%CC\%A7a-Manual-de-Boas-Pra\%CC\%81ticasem-Biosseguranc\%CC\%A7a-para-AmbientesOdontologicos.pdf

[17] Omidi L, Moradi G, Mostofi SN. Risk of COVID-19 infection in workplace. Work, 2020;66:377-378. http://dx. doi.org/10.3233/WOR-203188

[18] Irish Dental Association. Scale of dental collapse highlighted in survey. 2020.[Accessed 2020 Abr 30]. 
https://www.dentist.ie/latest-news/irish-dental-associat ion-warns-that-dental-profession-on-the-brink-ofcollapse.8336.html

[19] British Dental Association (BDAa). Live updates: coronavirus and dentistry. 2020. [Accessed 2020 Abr 30] https:// bda.org/advice/Coronavirus/Pages/latest-updates.Aspx

[20] Nasseh K, Vujicic M. Modeling the impact of COVID-19 on U.S. dental spending. Health Policy Institute Research Brief. American Dental Association. 2020. Available from: https://www.ada.org//media/ADA/Science\%20and\%20Re search/HPI/Files/HPIBrief_0420_1.pdf?la=en

[21] World Medical Association. Ethical principles for medical research involving human subjects. 59th WMA General Assembly, Seoul. 2008. [Accessed 2020 Oct 18]. https:// bda.org/advice/Coronavirus/Pages/latest-updates.As px https://www.wma.net/what-we-do/medical-ethics/decl aration-of-helsinki/doh-oct2008/

[22] Von Elm E, Altman DG, Egger M, Pocock SJ, Gøtzsche PC, Vandenbroucke JP. The Strengthening the Reporting of Observational Studies in Epidemiology (STROBE) Statement: Guidelines for reporting observational studies. Int $\mathbf{J}$ Surg. 2014;12(12):1495-9.

[23] Luiz RR, Magnanini MMF. A lógica da determinação do tamanho da amostra em investigações epidemiológicas. Cad Saúde Colet. 2000;8(2):9-28.

[24] Consolo U, Bellini P, Bencivenni D, Iani C, Checchi V. Epidemiological Aspects and Psychological Reactions to COVID-19 of Dental Practitioners in the Northern Italy Districts of Modena and Reggio Emilia. Int J Environ Res Public Health. 2020;17(10):3459-76. http://dx.doi. org/10.3390/ijerph17103459

[25] Ahmed MA, Jouhar R, Ahmed N, Adnan S, Aftab M, Zafar MS, et al. Fear and Practice Modifications among Dentists to Combat Novel Coronavirus Disease (COVID-19) Outbreak. Int J Environ Res Public Health. 2020;17(8):2821-32. http://dx.doi.org/10.3390/ijerph17082821

[26] Shacham M, Hamama-Raz Y, Kolerman R, Mijiritsky O, Ben-Ezra M, Mijiritsky E. COVID-19 Factors and Psychological Factors Associated with Elevated Psychological Distress among Dentists and Dental Hygienists in Israel. Int J Environ Res Public Health. 2020;17(8):1-7. http://dx.doi.org/10.3390/ijerph17082900

[27] Ferneini EM. The Financial Impact of COVID-19 on Our Practice. J Oral Maxillofac Surg. 2020. http://dx.doi. org/10.1016/j.joms.2020.03.045

[28] Almeida-Leite CM, Stuginski-Barbosa J, Conti PCR. How psychosocial and economic impacts of COVID-19 pandemic can interfere on bruxism and temporomandibular disorders? J Appl Oral Sci. 2020;28. http://dx.doi. org/10.1590/1678-7757-2020-0263

[29] Kaur M, Goyal P, Goyal M. Individual, interpersonal and economic challenges of underemployment. Work. 2020;67:21-28. http://dx.doi.org/10.3233/WOR-203249

[30] British Dental Association (BDAb). Practices Weeks from Collapse without Rapid Action from Government. 2020. [Accessed: 2020 Nov 26]. Available online: https:// www.bda.org/news-centre/press-releases/Pages/Practicesmonths-from-collapse-without-rapid-action-from-UKgovernment.aspx
[31] Guo H, Zhou Y, Liu X, Tan J. The impact of the COVID-19 epidemic on the utilization of emergency dental services. J Dent Sci. 2020. http://dx.doi.org/10.1016/j.jds.2020.02.002

[32] Isiekwe IG, Adeyemi TE, Aikins EA, Umeh OD. Perceived impact of the COVID-19 pandemic on orthodontic practice by orthodontists and orthodontic residents in Nigeria. J World Fed Orthod. 2020;9(3):123-28. http://dx.doi.org/10.1016/j.ejwf.2020.07.001

[33] Costa DS, Rocha MP. O Cirurgião-Dentista e o Mercado de Trabalho no Brasil: uma revisão sistemática da literatura. Id on line R Psic. 2017;11(38):102-14. http://dx.doi.org/10.14295/idonline.v11i38.883

[34] Schwendicke F, Krois J, Gomez J. Impact of SARS-CoV2 (Covid-19) on dental practices: Economic analysis. J Dent. 2020. http://dx.doi.org/10.1016/j.jdent.2020.103387

[35] Barabari P, Moharamzadeh K. Novel Coronavirus (COVID19) and Dentistry-A Comprehensive Review of Literature. Dent J. 2020;8(2):53. http://dx.doi.org/10.3390/dj8020053

[36] Liu M, Cheng SZ, Xu KW, Yang Y, Zhu QT, Zhang H, et al. Use of personal protective equipment against coronavirus disease 2019 by healthcare professionals in Wuhan, China: cross sectional study. BMJ. 2020;369:m2195. http://dx.doi.org/10.1136/bmj.m2195

[37] Chamorro-Petronacci C, Carreras-Presas CM, Sanz-March ena A, Rodríguez-Fernández MA, Suárez-Quintanilla JM, Rivas-Mundiña B, et al. Assessment of the Economic and Health-Care Impact of COVID-19 (SARS-CoV-2) on Public and Private Dental Surgeries in Spain: a pilot study. Int J Environ Res Public Health. 2020;17(14):5139. http://dx.doi.org/10.3390/ijerph17145139

[38] Van Der Tas J, Dodson T, Buchbinder D, Fusetti S, Grant M, Leung YY, et al. The Global Impact of COVID-19 on Craniomaxillofacial Surgeons. Craniomaxillofac Trauma Reconstr. 2020;13(3):157-67. http:// dx.doi.org/10.1177/1943387520929809

[39] Proffitt E. What will be the new normal for the dental industry? $\mathrm{Br}$ Dent J. 2020;228(9):678-680. http://dx.doi.org/10.1038/s41415-020-1583-x

[40] Moraes RR, Correa MB, Queiroz AB, Daneris A, Lopes JP, Pereira-Cenci T, et al. COVID-19 challenges to dentistry in the new pandemic epicenter: Brazil. BMJ. 2020. http://dx.doi.org/10.1101/2020.06.11.20128744

[41] Ali S, Farooq I, Abdelsalam M, Alhumaid J. Current Clinical Dental Practice Guidelines and the Financial Impact of COVID-19 on Dental Care Providers. Eur J Dent. 2020. http://dx.doi.org/10.1055/s-0040-1716307

[42] Conselho Federal de Odontologia (CFO). Coronavírus: CFO solicita ao ministro da Economia medidas para redução de impacto econômico aos profissionais da Odontologia. [Acessed: 2020 Nov 26]. Available online: https://website.cfo.org.br/coronavirus-cfo-solicita-aoministro-da-economia-medidas-para-reducao-de-impactoeconomico-aos-profissionais-da-odontologia/ 